\title{
Life-threatening hyponatraemia
}

\author{
Emmanuel Eroume A Egom, ${ }^{1}$ Kenneth Y-K Wong, ${ }^{2}$ Andrew L Clark ${ }^{2}$
}

${ }^{1}$ Academic Cardiology, University of Hull, Hull and East Yorkshire Hospitals, Kingston upon Hull, UK;

${ }^{2}$ Academic Cardiology, University of Hull, Kingston upon Hull, UK

Correspondence to Dr Emmanuel Eroume A Egom, eeroumeaegom@doctors.org.uk

\section{Summary}

A 31-year-old hypertensive woman was admitted to hospital with palpitations. Her hypertension was treated with bendroflumethiazide, which had been increased from 2.5 to $5 \mathrm{mg}$ daily by her general practitioner about 18 months prior to her admission. She was also on ramipril $10 \mathrm{mg}$ once daily. There were no abnormal findings on examination, and a 12-lead ECG showed sinus rhythm, rate 75, with 0 waves in leads V1-V2. Telemetry (over $24 \mathrm{~h}$ ) showed ventricular bigeminy when she had her typical palpitations. Her admission serum sodium and potassium concentrations were 132 and $3.4 \mathrm{mmol} / \mathrm{l}$, respectively. Immediately prior to planned discharge the following day, she experienced paraesthesiae, weakness, confusion and seizures accompanied by $10 \mathrm{~s}$ asystole on the ECG monitor. Her serum sodium had fallen to 120 $\mathrm{mmol} / \mathrm{l}$ and potassium to $2.3 \mathrm{mmol} / \mathrm{l}$. Bendroflumethiazide and ramipril were discontinued and the patient was restricted to fluids of 1.5 l/24 h. She also received potassium supplements. Her serum sodium concentration rose to normal over 6 days, and she was discharged on feeling well.

\section{BACKGROUND}

The use of thiazide diuretics is a common cause of severe hyponatraemia. The incidence of hyponatraemia is increasing as a result of guidelines recommending thiazides for the treatment of essential hypertension in many patients. The impact of thiazide-induced hyponatraemia has recently been reviewed, but little attention has been given to the practical approach on the prevention of this time-honoured medication complication. We describe a case of life-threatening thiazide-induced hyponatraemia (TIH) in a young woman who presented to hospital with palpitations, and suggest an approach to the prevention of thiazide-induced hyponatraemia in the hope that increased awareness and understanding will reduce the incidence and complications of this potentially life-threatening condition.

\section{CASE PRESENTATION}

A 31-year-old woman was admitted to hospital with palpitations. Her medical history included essential hypertension, recurrent episodes of syncope and Crohn's disease. Her hypertension was treated with bendroflumethiazide, which had been increased from 2.5 to $5 \mathrm{mg}$ daily by her general practitioner about 18 months prior to her admission. She was also treated with ramipril $10 \mathrm{mg}$ once daily and mesalazine $800 \mathrm{mg}$ twice daily. She denied cough, fever, weight loss or smoking. On examination, she was fully alert and orientated and had no abnormal pigmentation. Arterial pulse was 71 in sinus rhythm, and blood pressure (BP) was 120/65. There were no abnormal findings on examination, and a 12-lead ECG showed sinus rhythm, rate 75 . There were $\mathrm{Q}$ waves in leads V1-V2. Telemetry (over $24 \mathrm{~h}$ ) showed ventricular bigeminy when she had her typical palpitations. Her admission serum sodium and potassium concentrations were 132 and $3.4 \mathrm{mmol} / \mathrm{l}$, respectively. Immediately prior to planned discharge the next day, she had a vasovagal episode while withdrawing blood. She was kept in for further monitoring. That evening, she experienced paraesthesiae, weakness, vomiting, confusion and seizures accompanied by $10 \mathrm{~s}$ asystole on the ECG monitor.

\section{INVESTIGATIONS}

Admission laboratory tests included serum sodium concentration $132 \mathrm{mmol} / \mathrm{l}$, potassium $3.4 \mathrm{mmol} / \mathrm{l}$, urea 4.2 $\mathrm{mmol} / \mathrm{l}$ and creatinine $59 \mu \mathrm{mol} / \mathrm{l}$. Full blood count, thyroid stimulating hormone and troponin I were normal.

The day after admission, her serum sodium had fallen to $120 \mathrm{mmol} / \mathrm{l}$ and potassium to $2.3 \mathrm{mmol} / \mathrm{l}$. Urinary osmolality was $212 \mathrm{mOsm} / \mathrm{kg}$, serum osmolality was $247 \mathrm{mOsm} /$ $\mathrm{kg}$ and urinary sodium was less than $10 \mathrm{mmol}^{-1}$.

\section{DIFFERENTIAL DIAGNOSIS}

- Drug induced - bendrofluazide $5 \mathrm{mg}$ once daily and ramipril $10 \mathrm{mg}$ once daily.

- Water intoxication - she admitted that she had been drinking 'a lot of water' for 2 days before and then during her admission. She might have drunk about 3-4 1/ day, which was more than usual for her.

- Crohn's disease: the patient had not had diarrhoea recently, nor had she been vomiting before admission.

- Renal failure: renal function was normal.

- Heart failure: no clinical evidence.

- Syndrome of inappropriate antidiuretic hormone ADH (SIADH) causes: Our patient's urinary osmolality was $212 \mathrm{mOsm} / \mathrm{kg}$, which was lower than her serum osmolality $(247 \mathrm{mOsm} / \mathrm{kg})$ and her urinary sodium was less than $10 \mathrm{mmol}^{-1}$. Her chest $\mathrm{x}$-ray and CT scan of her head were normal.

- Liver failure and alcoholism: liver function tests and albumin were normal. The patient did not normally drink alcohol and had none for weeks before admission. 
- Adrenal crisis: potassium was not high and short Synacthen test was normal.

- Drugs and toxins: patient denied use of over-the-counter or recreational or illicit substances.

- Hypothyroidism: thyroid function test was normal.

- Pseudohyponatraemia due to significant hyperlipidaemia, hyperproteinaemia or hyperglycaemia. In this case, cholesterol was $4.5 \mathrm{mmol} / \mathrm{l}$, high density lipoprotein 1.2 , low density lipoprotein 2.9 and triglyceride was only $0.8 \mathrm{mmol} / 1$. Glucose, protein and calcium were all normal.

\section{TREATMENT}

Bendroflumethiazide and ramipril were discontinued and the patient was restricted to fluids of $1.51 / 24 \mathrm{~h}$. She also received potassium supplements.

\section{OUTCOME AND FOLLOW-UP}

Her serum sodium concentration rose to the normal range over 6 days (figure 1), and she was discharged on feeling well. BP at discharge was 115/63 and she was not on medication.

\section{DISCUSSION}

Thiazide diuretics cause hyponatraemia by blocking sodium chloride co-transport in the distal convoluted tubule. As a result, sodium excretion is increased, while excretion of free water is reduced. ${ }^{12}$ Depending upon the populations studied, hyponatraemia may be seen in up to $17 \%$ of patients receiving a thiazide diuretic. Even in the systolic hypertension in the Elderly Program, $4.1 \%$ of patients treated with a thiazide diuretic (vs 1.3\% in the control group) developed hyponatraemia (defined as serum sodium $<135 \mathrm{mmol} / \mathrm{l}){ }^{3}$ The major risk factors for TIH are old age, female sex, lower body weight, hypokalaemia and concurrent use of other drugs that impair free water excretion. ${ }^{14-6}$ Although our patient is young, she had concurrent hypokalaemia and was not only on thiazide, but also ramipril, which might cause a decrease in sodium. Ninety percent of patients with hypertension in this age group have primary or essential hypertension. Only a small percentage of patients $(5-10 \%)$ have secondary hypertension. In this case, 24-h ambulatory BP monitoring (off antihypertensive) suggests she probably has hypertension but no obvious secondary causes for her hypertension were found. TIH is not benign: there were 12 deaths in a group of 129 cases of severe diuretic-related hyponatraemia in one review. ${ }^{4}$

Thiazide-induced hyponatraemia usually occurs within 2 weeks of starting, but it can occur within a day or two or even after a single dose when there are predisposing factors. ${ }^{4} 7$ In patients who are hypovolaemic, ADH is stimulated and contributes to reduced free water excretion. In contrast, in euvolaemic or hypervolaemic patients, $\mathrm{ADH}$ is usually suppressed and is not contributory. ${ }^{8}$ Drugs such as ecstasy may be associated with the syndrome of inappropriate $\mathrm{ADH}$ secretion, which predisposes to hyponatraemia. In this case it is unlikely that SIADH was present because the patient had a low urinary sodium and a normal urinary osmolality. Furthermore, the effect of ecstasy generally occurs within 30-60 min of consumption, hitting a peak at approximately $1-1.5 \mathrm{~h}$, reaching a plateau that lasts about $2-3 \mathrm{~h}$, followed by a return to baseline of a few hours, which may be accompanied by fatigue and minor effects. In our case, the patient developed acute hyponatraemia more than $24 \mathrm{~h}$ after admission. We cannot be certain about what happened during her apparent episode of prolonged asystole with syncope when her sodium had dropped significantly. She had had episodes of syncope

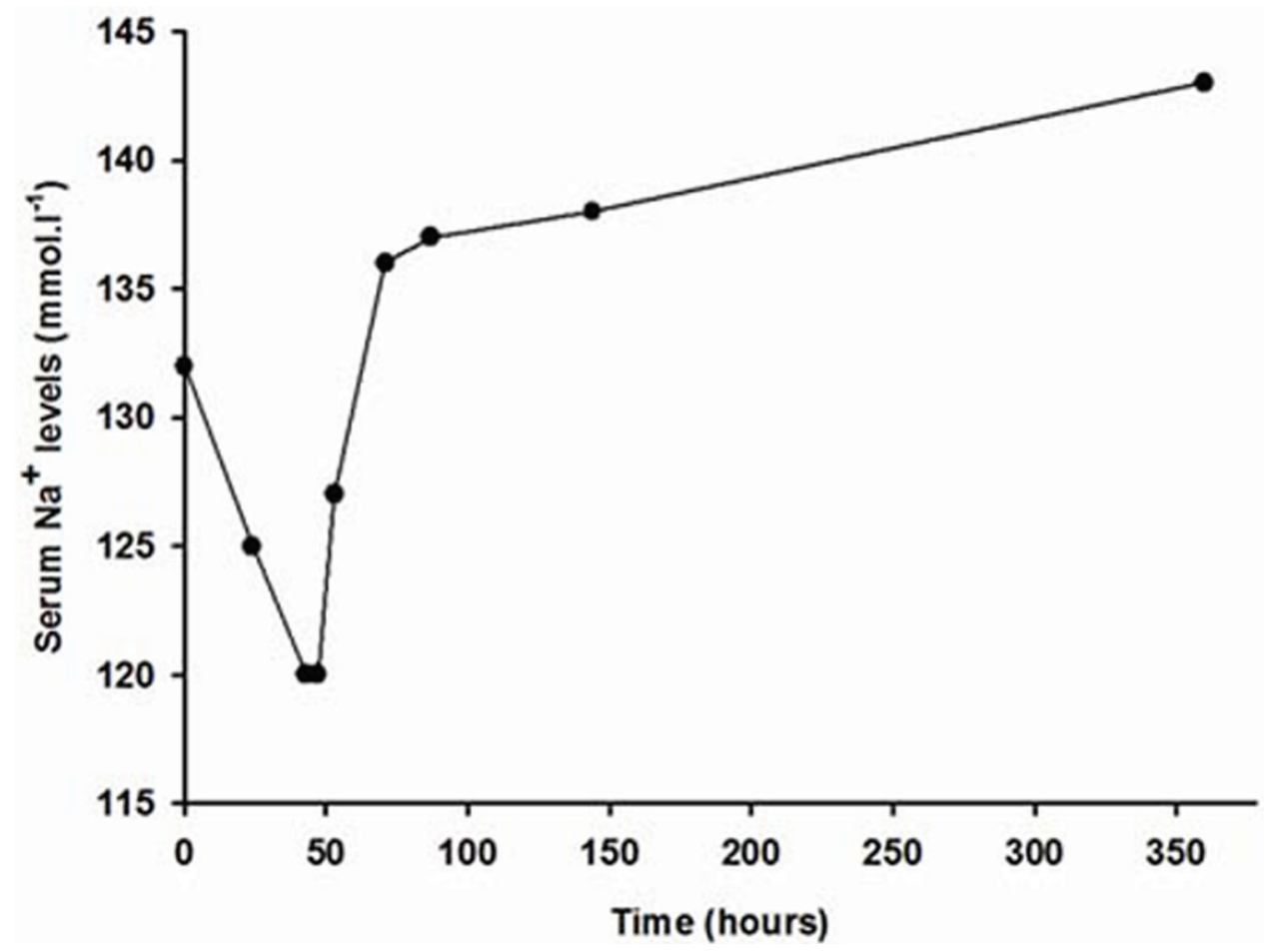

Figure 1 Serum sodium $\left(\mathrm{Na}^{+}\right)$levels during the patient's admission. 
before admission and the mechanism might be vagal, exacerbated by treatment for hypertension. During the admission, she had at least two vasovagal episodes due to vascular access (one was related to venepuncture; the other occurred around the time of arterial access). However, the episode of prolonged asystole occurred as part of her presentation with hyponatraemia, and we cannot exclude the possibility that the syncope was related.

Acute management of hyponatraemia is determined more by the presence of neurological symptoms than by the sodium level per se. Patients with acute onset of hyponatraemia (decrease in sodium concentration to less than $120 \mathrm{mmol} / \mathrm{l}$ in less than $48 \mathrm{~h}$ ) are more likely to be symptomatic and are more at risk of cerebral oedema than those in whom hyponatraemia developed more gradually. ${ }^{9}$ The treatment is to stop the thiazide, and to restrict water intake. In patients with severe manifestations such as seizures or coma, hypertonic saline may be used, ${ }^{8}$ but only with great care and should only be given by experienced teams with close supervision because of the risk of central pontine myelinolysis. ${ }^{9}$ In patients with mild or no symptoms, counselling about the risks and benefits of the continued use of the thiazide diuretic, avoidance of excessive water intake and careful monitoring of the serum sodium level usually provide good outcome.
Acknowledgements The authors would like to thank Hull and East Yorkshire Hospitals, National Institute for Health Research (NIHR), Yorkshire and the Humber Deanery, and Hull York Medical School (HYMS).

Competing interests None.

Patient consent Obtained.

\section{REFERENCES}

1. Clark BA, Shannon RP, Rosa RM, et al. Increased susceptibility to thiazideinduced hyponatremia in the elderly. J Am Soc Nephrol 1994;5:1106-11.

2. Spital A. Diuretic-induced hyponatremia. Am J Nephrol 1999;19:447-52.

3. Group ScR. Prevention of stroke by antihypertensive drug treatment in older persons with isolated systolic hypertension. Final results of the Systolic Hypertension in the Elderly Program (SHEP). SHEP Cooperative Research Group. JAMA 1991:265:3255-64.

4. Sonnenblick M, Friedlander Y, Rosin AJ. Diuretic-induced severe hyponatremia. Review and analysis of 129 reported patients. Chest 1993; 103:601-6.

5. Chow KM, Szeto CC, Wong TY, et al. Risk factors for thiazide-induced hyponatraemia. OJM 2003;96:911-17.

6. Walker RM, Brown RS, Stoff JS. Role of renal prostaglandins during antidiuresis and water diuresis in man. Kidney Int 1982;21:365-70.

7. Sharabi Y, Illan R, Kamari Y, et al. Diuretic induced hyponatraemia in elderly hypertensive women. J Hum Hypertens 2002;16:631-5.

8. Mann SJ. The silent epidemic of thiazide-induced hyponatremia. J Clin Hypertens (Greenwich) 2008;10:477-84.

9. Adrogué HJ. Consequences of inadequate management of hyponatremia Am J Nephrol 2005;25:240-9.

\section{Learning points}

- Consider thiazide-induced hyponatraemia in all cases of acute hyponatraemia.

- To prevent symptomatic thiazide-induced hyponatraemia, electrolytes should be measured within 2 weeks of starting treatment. ${ }^{9}$

- The serum sodium may fall within hours of diuretic administration, and severe hyponatraemia can develop within 2 days in susceptible individuals. In susceptible patients, serum sodium should be measured within 1 or 2 days after beginning thiazide therapy.

- Even patients who have done well on chronic thiazide therapy may still develop severe hyponatraemia if water intake increases ${ }^{2}$ as in this case, and so advice on fluid intake is very helpful.

This pdf has been created automatically from the final edited text and images.

Copyright 2011 BMJ Publishing Group. All rights reserved. For permission to reuse any of this content visit http://group.bmj.com/group/rights-licensing/permissions.

BMJ Case Report Fellows may re-use this article for personal use and teaching without any further permission.

Please cite this article as follows (you will need to access the article online to obtain the date of publication).

Egom EEA, Wong KYK, Clark AL. Life-threatening hyponatraemia. BMJ Case Reports 2011;10.1136/bcr.12.2010.3594, date of publication

Become a Fellow of BMJ Case Reports today and you can:

- Submit as many cases as you like

- Enjoy fast sympathetic peer review and rapid publication of accepted articles

- Access all the published articles

- Re-use any of the published material for personal use and teaching without further permission

For information on Institutional Fellowships contact consortiasales@bmjgroup.com

Visit casereports.bmj.com for more articles like this and to become a Fellow 